\title{
THE DETECTION OF Plasmodiophora brassicae USING LOOP-MEDIATED ISOTHERMAL DNA AMPLIFICATION
}

\author{
Joanna Kaczmarek ${ }^{1}$, Witold Irzykowski ${ }^{1}$, Adam Burzyński ${ }^{2}$, Małgorzata Jędryczka ${ }^{1 \#}$ \\ ${ }^{1}$ Institute of Plant Genetics, Polish Academy of Sciences, Strzeszyńska 34, 60-479 Poznań, Poland \\ ${ }^{2}$ Novazym Polska, Poznań Science and Technology Park, Rubież 46, Poznań, Poland \\ \# e-mail: mjed@igr.poznan.pl
}

Received: 10.09.2014

\begin{abstract}
Plasmodiophora brassicae, the cause of clubroot, is a very serious problem preventing from successful and profitable cultivation of oilseed rape in Poland. The pathogen was found in all main growing areas of oilseed rape; it also causes considerable problems in growing of vegetable brassicas. The aim of this work was to elaborate fast, cheap and reliable screening method to detect $P$. brassicae. To achieve this aim the Loopmediated isothermal DNA amplification (LAMP) technique has been elaborated. The set of three primer pairs was designed using LAMP software. The detection was performed with the GspSSD polymerase, isolated from bacteria Geobacillus sp., with strand displacement activity. DNA extraction from clubbed roots obtained from farmers' fields of oilseed rape infected by $P$. brassicae was done using a modified CTAB method. The reaction was performed for $60 \mathrm{~min}$ at $62^{\circ} \mathrm{C}$. The visual detection was done using CFX96 Real Time PCR Detection System (BioRad) or Gerie II Amplicatior (Optigen). The detection with LAMP proved its usefulness; it was easy, fast and accurate and independent of plant age. The detection limit was 5 spores per $1 \mu \mathrm{l}$ of the spore suspension, so LAMP was less sensitive than quantitative PCR tests reported in the literature. However, the method is cheap and simple, so it is a good alternative, when it comes to practical use and the assessment of numerous samples.
\end{abstract}

Key words: clubroot; isothermal DNA amplification; Plasmodiophora brassicae; oilseed rape; GspSSD polymerase; strand displacement activity; loop-mediated isothermal DNA amplification, LAMP.

\section{INTRODUCTION}

Plasmodiophora brassicae Woronin is an obligate biotrophic pathogen of crops belonging to Brassicaceae family $[1,2]$. According to the recent phylogenomic analyses based on ESTs it belongs to the group of Phytomyxea, which is a part of the supergroup of
Rhizaria. This taxonomic group is regarded as one of the most poorly understood supergroups of eukaryotes [3]. However, newly available transcriptome studies allowing to perform phylogenomic analyses of very small amounts of material provided deeper insights in early evolution of eucaryotes and generated large amounts of data [4]. The studies include parasitic protists, such as $P$. brassicae. Other important plant pathogens, such as Spongospora subterranea - the causal agent of powdery scab on potato, also belong to Rhizaria and Phytomyxea. Both pathogens are found worldwide, where the host plants are consistently grown, and their effect on yield is high. They either directly reduce the amount of collected seeds of cruciferous plants, as is the case of $P$. brassicae, or the effect on yield is indirect, through the unmarketable, scabbed appearance of potato tubers, as for S. subterranea.

Plasmodiophora brassicae is responsible for clubroot, the disease known on cruciferous crops in Europe since at least the XIII century [1]. Subsequently, the pathogen probably spread worldwide on and in fodder taken by colonists as livestock feed [2]. In Poland for many years it was posing a serious threat to vegetable brassicas [5]. However, in recent time clubroot is a very serious problem preventing from successful and profitable cultivation of oilseed rape [6].

Spring canola and winter oilseed rape are essential sources of vegetable oil in human and livestock foodstuffs [2], as well as industrial products such as biodiesel and lubricants $[7,8]$. The crop is bringing one of the highest profits to farmers in all important growing areas of oilseed rape located in Europe, Canada, Australia, China and India, so a disease that decreases its yield is highly undesirable. Also in Poland, the problem is serious as the disease is present in all agronomic regions with a high share of oilseed rape in a sowing 
structure [6]. The pathogen is very persistent in soil [9], but until recently the spread of virulent $P$. brassicae pathotypes was regarded as relatively slow [10].

Agricultural practice and numerous research studies require the knowledge about the presence and concentration of the pathogen in plants, soil and water. Recent studies of primary and secondary infection processes by $P$. brassicae on canola showed that early stages of infection of canola roots required $1 \times 10^{5}$ resting spores $\mathrm{mL}^{-1}$ for primary (root hair) infection at $12 \mathrm{~h}$ after inoculation, whereas secondary (cortical) infection began to be observed 3 days after inoculation. When inoculated onto plants at a concentration of $1 \times 10^{4} \mathrm{~mL}^{-1}$, secondary zoospores produced primary infections similar to those obtained with resting spores at a concentration of $1 \times 10^{5} \mathrm{~mL}^{-1}$ [11]. In general, the level of $10^{3}$ spores per $1 \mathrm{~g}$ of soil is regarded as the concentration of the spores of $P$. brassicae required to produce symptoms on plants and the level of $3 \times 10^{3} \mathrm{P}$. brassicae resting spores $\mathrm{g}^{-1}$ soil, is suggested for growing resistant cultivars [12]. Cultivation of resistant varieties has been by now regarded as the most effective method of controlling clubroot in many cropping areas [10]. In agricultural practice it is also important to make sure that clubs on roots are resulting from the infection by $P$. brassicae and not from other reasons, such as the damage caused by gall-forming root weevils Ceutorhynchus pleurostigma Marsham [=C. assimilis Paykull] or C. cardariae Korotyaev.

To achieve this aim different molecular tests has been proposed by some researchers. It was already nearly 20 years ago when the single copy DNA sequence unique to $P$. brassicae have cloned [13] and then used to develop a nested PCR-based technique allowing to detect $P$. brassicae resting spores in soil [14]. At the same time a similar technique, with the use of specific PCR primers was also proposed for the detection of the pathogen not only from soil, but also from water samples [15]. In 2001 the technique of nested PCR was successfully used in Poland to prove the usefulness of the treatment of field soil and peat moss substrate with IBE 3878 fungicide or hot steam. Both treatments lowered the concentration of resting spores below $10^{3}$ per $1 \mathrm{~g}^{-1}$ of soil, what was the detection limit of this method [16].

In 2007, C a o et al. [17] developed a simple, one-step PCR-based protocol allowing to detect the pathogen in plant and soil samples, whereas in recent years two quantitative PCR protocols were proposed $[12,18]$. The method by Walle $\mathrm{nhammar}$ et al. [12] used species-specific primers and a TaqMan fluorogenic probe designed to amplify a small region of $P$. brassicae ribosomal DNA. The detection limit in soil samples corresponded to 500 resting spores $\mathrm{g}^{-1}$ soil. The detection limit of the method described by $\mathrm{Li}$ et al. [18] was lower as it corresponded to $10^{3}$ resting spores $\mathrm{g}^{-1}$ soil, but the method was cheaper, as it was based on a SYBR Green chemistry and speciesspecific primers of $P$. brassicae, amplifying the conservative region of rDNA-ITS. Both tests, although very specific and sensitive require many steps of DNA purification and expensive reagents as well as high laboratory skills. The aim of this work was to elaborate fast, cheap and reliable screening method to detect $P$. brassicae, for its further use in different substrates, such as plants, soil and water.

\section{MATERIALS AND METHODS}

\section{Plant sampling}

Plant samples were collected from glasshouse experiments carried out to evaluate the pathotypes of Plasmodiophora brassicae, based on the system designed by S omé et al. [19]. Differential reaction on Brassica napus ECD06, ECD10 and cv. Brutor assigned tested single-club isolates to five groups P1 to P5. A clubbed root from each pathotype was then homogenised using high-performance Ultra Tur$\operatorname{rax}$ T25 Digital homogeniser with S25N-10G and S25-18G dispersing elements. The spores were adjusted to $5 \times 10^{6}$ per $1 \mathrm{~mL}$ of the spore suspension and then mixed in equal proportions. They were then used to assess the resolution of the method. The test was also performed using five field isolates of P. brassicae, collected in different regions of Poland: 1) Siemyśl (N 5401'38.9' E 15³1'57.3'), West Pomera-

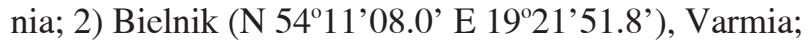

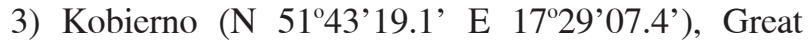
Poland; 4) Wrzesiny (N 51 $42^{\prime} 11.7^{\prime}$ E $15^{\circ} 26^{\prime} 02.6^{\prime}$ ), Lubusz region; 5) Gorzanowice (N 50 56'38.9' E 16 04'57.6'), Lower Silesia. The location of these sites is shown in Fig. 1.

\section{Extraction of DNA}

To extract DNA of $P$. brassicae the solution of resting spores was placed in Eppendorf tubes with $20 \mathrm{mg}$ of $\mathrm{SiC}$ and $650 \mu \mathrm{L} \mathrm{CTAB}$ (hexadecyltrimethylammonium bromide) extraction buffer. The CTAB buffer contained $100 \mathrm{mM}$ TRIS-HCl, pH 8.0; $20 \mathrm{mM}$ EDTA, $\mathrm{pH} 8.0 ; 1.4 \mathrm{M} \mathrm{NaCl}$. The mixture was heated at $65^{\circ} \mathrm{C}$ for $20 \mathrm{~min}$. and then it was shaken with $\mathrm{CHCl}_{3}$. The extract was acidified with $\mathrm{CH}_{3} \mathrm{COOK}(3 \mathrm{M}$, $\mathrm{pH}$ 5.4), it was kept on ice and then vortexed. The aqueous phase was collected and DNA was extracted using pure ice cold ethanol (99.8\%). The sediment was dissolved in TE (10 mM Tris-HCl, $0.1 \mathrm{mM}$ EDTA) buffer and this solution was used for LAMP reactions. To test the resolution of the method the $10 \times, 100 \times$ and $1.000 \times$ dilutions of template DNA were made. 


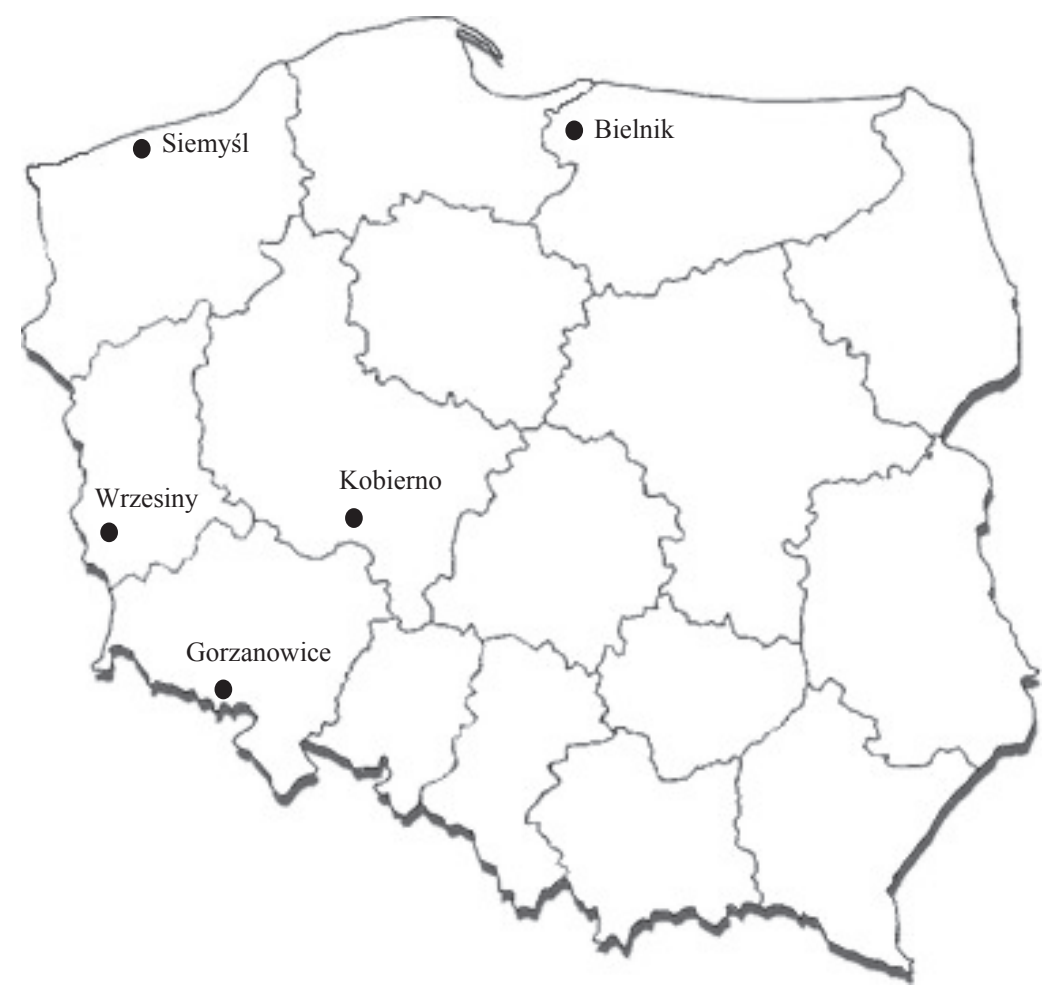

Fig. 1. The origin of the field samples of Plasmodiophora brassicae (clubbed roots) from different regions of Poland used in this study.

\section{Pathogen detection by LAMP method}

The LAMP assay was performed using $12.5-\mu \mathrm{L}$ a reaction mixtures containing $1 \mu \mathrm{L}$ of template DNA or its $10 \times, 100 \times$ and $1.000 \times$ dilutions. The reaction mix contained $1.6 \mu \mathrm{M}$ each of inner primers FIP and BIP, $0.2 \mu \mathrm{M}$ each of outer primers F3 and B3, and $0.8 \mu \mathrm{M}$ of loop primers LF and LB, Isothermal Mastermix - fluorescent dye 1x (Optigene, UK). The reaction mixture was incubated at $62^{\circ} \mathrm{C}$ for $60 \mathrm{~min}$ and then at $85^{\circ} \mathrm{C}$ for $2 \mathrm{~min}$ to complete the reaction. The visual detection was done using CFX96 Real Time PCR Detection System (BioRad) or Gerie II Amplificator (Optigene).

\section{RESULTS}

The detection of the DNA extracted from the mixture of resting spores of P1-P5 pathotypes of $P$. brassicae was successful using the described protocol. The LAMP product was generated in case of all used dilutions of the DNA template (Fig. 2).

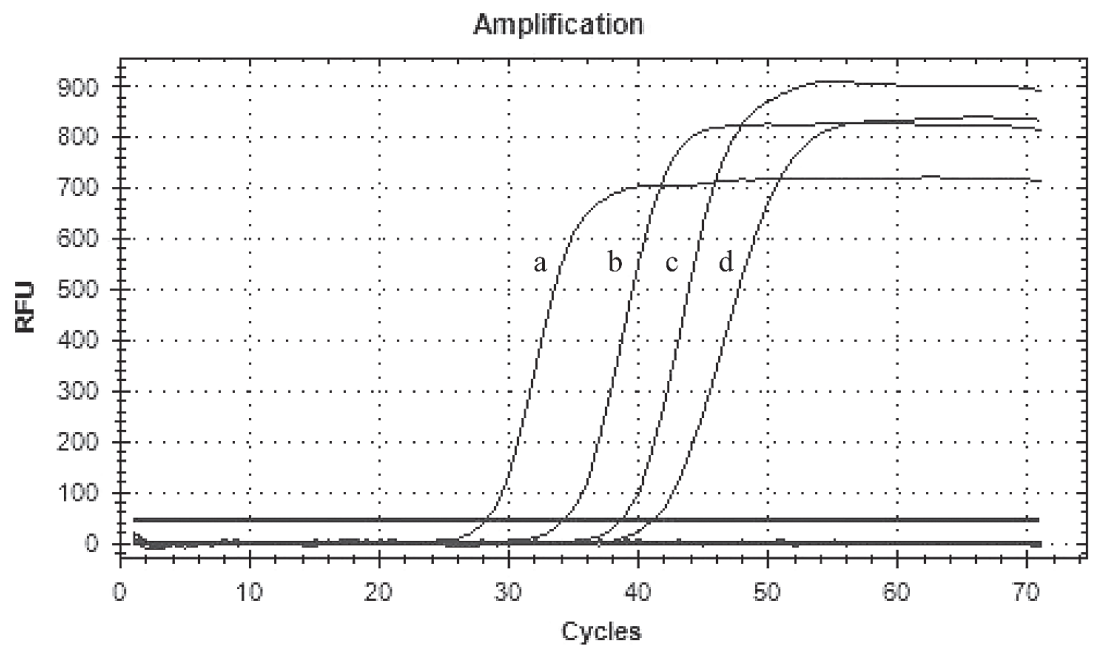

Fig. 2. Resolution of Loop-mediated isothermal DNA amplification (LAMP) of Plasmodiophora brassicae, using $1 \mu \mathrm{L}$ of: a)

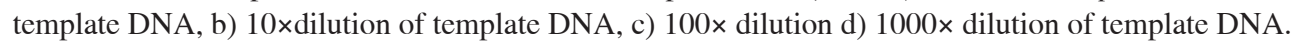


The melting curve was of appropriate shape, without any additional peaks due to unwanted LAMP products or primer dimers (Fig. 3).
The LAMP method was also successful in the detection of the pathogen from randomly collected plant root samples originating directly from fields infected by $P$. brassicae, collected in different regions of Poland.

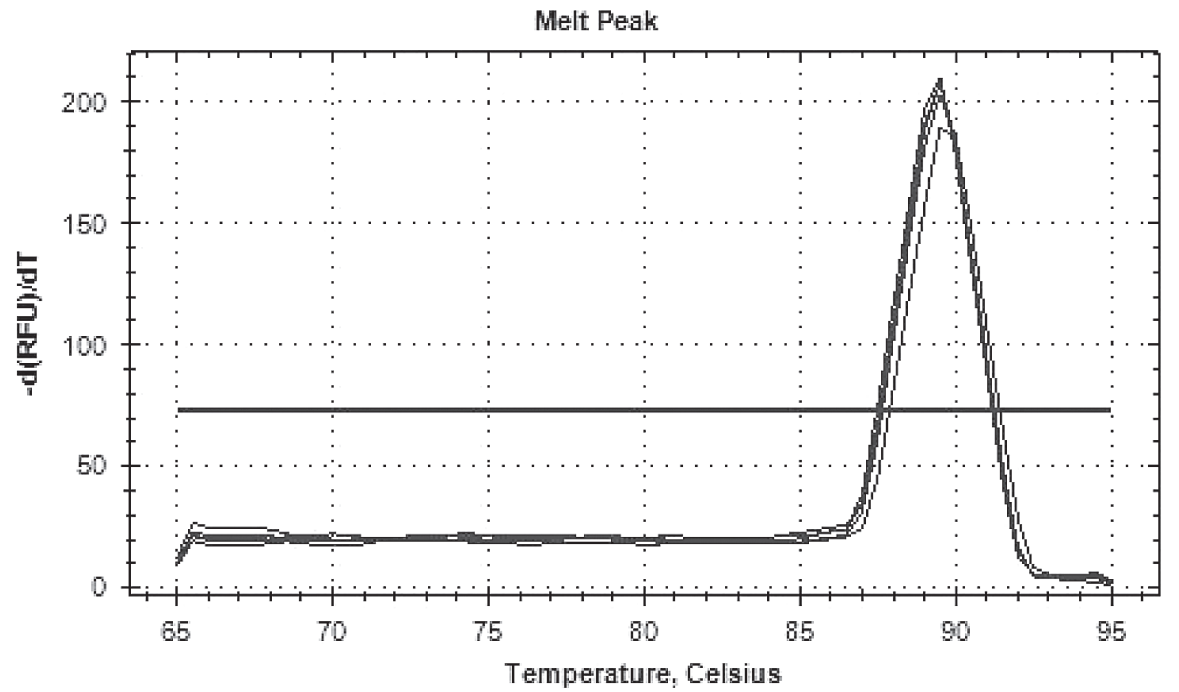

Fig. 3. Melting curve of the Loop-mediated isothermal DNA amplification (LAMP) of Plasmodiophora brassicae product (ITSbased).

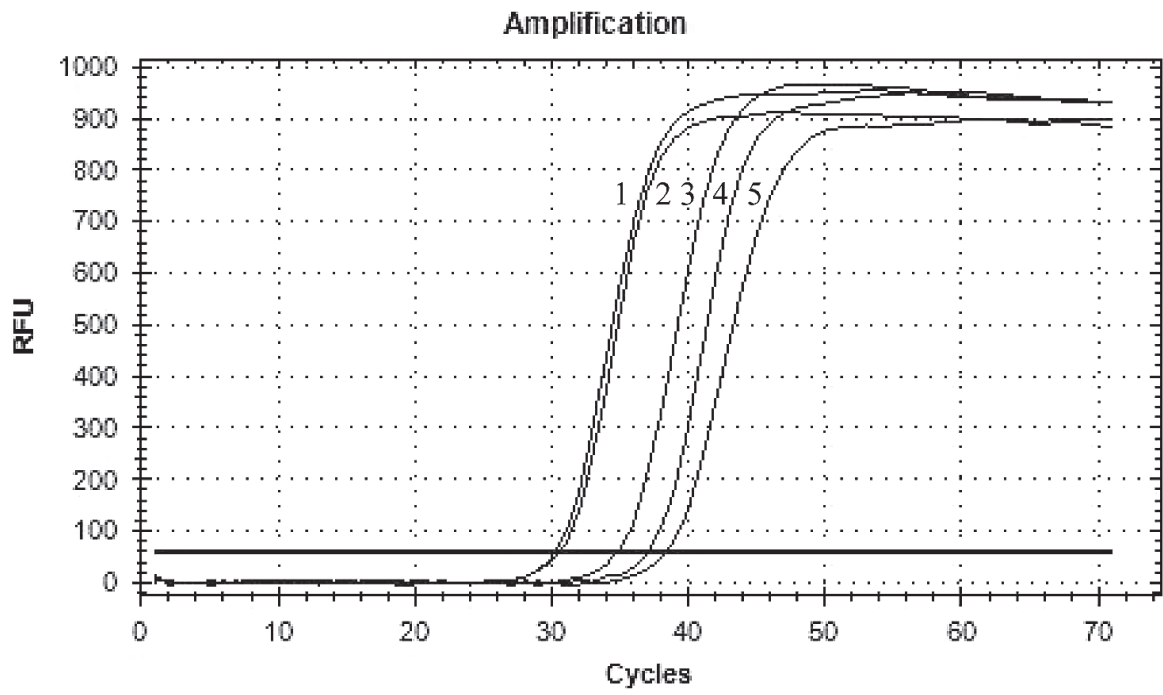

Fig. 4. Detection of Plasmodiophora brassicae from various samples using LAMP method: 1) Bielnik, Varmia; 2) Gorzanowice, Lower Silesia; 3) Siemyśl, West Pomerania; 4) Wrzesiny, Lubusz region; 5) Kobierno, Great Poland.

\section{DISCUSSION}

Serious problems with high incidence and very big severity of clubroot on Brassicaceae crops, especially on cultivated brassicas, require quick, sensitive but robust methods of pathogen detection. In case of uncultivable microorganisms, such as $P$. brassicae, belonging to Rhizaria, the visual recognition in clubbed roots is a too late step to undertake the appropriate measures to control the disease. The technique of Loopmediated isothermal DNA amplification has numerous advantages that seems beneficial to monitor the disease development in its early steps: it allows to perform the reaction in a quick manner, using simple tools and relatively cheap reagents [20,21], and it is very sensitive due to the use of loop primers [22].

Pathogen populations, even the ones belonging to the same species usually greatly differ in many characters [23-25]; so is the case of $P$. brassicae, where a large variation of pathotypes and physiological specialization has been reported [26-28]. LAMP method proved its usefulness for the detection of resting spores 
of $P$. brassicae of different origin. The experiments were successful both using infected plant material obtained from pure single-club isolates propagated in glasshouse conditions and infected plants obtained from farmers' fields located in different regions of Poland. The sensitivity of the method is $c a .5 .000$ spores per $1 \mathrm{~mL}$, so it is lower as compared to qPCR methods described in the literature [12,18], but it is sufficient for practical use. The lower detection limit is compensated with simplicity and low costs of testing, which are particularly preferred for everyday use and studies of numerous samples. It seems that the next necessary step to go is to develop pathotype-specific LAMP markers. A SCAR marker OPL14 1200 was already reported to detect P1 pathotype of $P$. brassicae [29], but the method was based on end-point PCR, so its sensitivity is most probably not sufficient enough for monitoring of minute amounts of the pathogen.

So far, species-specific detection using LAMP was proposed for some closely related species, such as Leptosphaeria maculans and L. biglobosa [30] or Nosema apis and N. ceranae [31], as well as methicillin-resistant Staphylococcus aureus (MRSA) in blood cultures [32] and virus subtype H5N1 of avian influenza [33]. The method proved its tolerance to culture media and biological substances, that can inhibit other molecular methods [34], so it seems that more pathogen detection tests will be soon developed, as it was forecasted by Tomlinson and Boonham [35]. These methods may be implemented and widely used not only in research studies but also by extension and sanitary services.

\section{CONCLUSION}

A loop-mediated isothermal DNA amplification method was developed for a rapid and sensitive detection of Plasmodiophora brassicae, a damaging pathogen causing clubroot of oilseed rape and vegetable brassicas. The method is cheap and simple, so it is a good alternative to quantitative PCR, when it comes to practical use for the assessment of numerous samples.

\section{Acknowledgements}

This work was supported by the project of the Ministry of Agriculture and Rural Development HOR hn-801-8/14 no 50.

\section{Authors' contributions}

Concept of the study: MJ; glasshouse experiment: MJ; design of primers: AB; DNA extraction and pathotype sequencing: WI, LAMP optimization and performance: JK; analysis of research results: MJ, JK; writing of the manuscript: MJ, JK.

\section{REFERENCES}

1 Agrios GN. Plant Pathology. Elsevier Academic Press; 2005.

2 Dixon GR. The occurrence and economic impact of Plasmodiophora brassicae and clubroot disease. J Plant Growth. Regul. 2009; 28: 194-202. http://dx.doi.org/10. 1007/s00344-009-9090-y.

3 Burki F, Keeling PJ.Rhizaria. Curr Biol.2014;24(3): R103-R107 http://dx.doi.org/10.1016/j.cub.2013.12.025.

4 Burki F, Kudryavtsev A, Matz MV, Aglyamova GV, Bulman S, Fiers M, Keeling PJ, Pawlowski J. Evalution of Rhizaria: new insights from phylogenomic analysis of uncultivated protists. BMC Evol Biol. 2010; 10: 377. http://dx.doi.org/10.1186/1471-2148-10-377.

5 Robak J. Zmienność patotypów Plasmodiophora brassicae Wor. występujących w Polsce i ich patogeniczność w stosunku do odmian i linii hodowlanych Brassica oleracea [Variability of Plasmodiophora brassicae Wor pathotypes. Occurring in Poland and their pathogenicity to cultivars and breeding lines of Brassica oleracea]. Habilitation monograph 1991, no 6. Instytut Warzywnictwa, Skierniewice, $61 \mathrm{pp}$.

6 Korbas M, Jajor E, Budka A. Clubroot (Plasmodiophora brassicae) - a threat for oilseed rape. J Plant Prot Res. 2009; 49(4): 446-451. http://dx.doi.org/10.2478/ v10045-009-0071-8.

7 Rashid U, Anwar F. Production of biodiesel through optimized alkaline-catalyzed transesterification of rapeseed oil. Fuel. 2008; 87(3): 265-273. http://dx.doi.org/10.1016/j. fuel.2007.05.003.

8 B ozbas K. Biodiesel as an alternative motor fuel: Production and policies in the European Union. Renewable and Sustainable Energy Reviews. 2008; 12(2): 542-552.

9 Dix on GR. Plasmodiophora brassicae and its environment. J Plant Growth Regul. 2009; 28: 212-228. http://dx. doi.org/10.1007/s00344-009-9098-3.

10 Diederichsen E, Frauen M, Linders EGA, Hat a keyama K, Hirai M. Status and perspectives of clubroot resistance breeding in crucifer crops. J Plant Growth Regul. 2009; 28: 265-281. http://dx.doi.org/10.10 07/s00344-009-9100-0.

11 Feng J, Hwang SH, Strelkov SE. Studies into primary and secondary infection processes by Plasmodiophora brassicae on canola. Plant Pathol. 2012; 62(1): 177-183. http://dx.doi.org/10.1111/j.1365-3059.2012.0261 2.x.

12 Wallenhammar AC, Almquist C, Jonsson A. In-field distribution of Plasmodiophora brassicae measured using quantitative real-time PCR. Plant Pathol. 2012; 61: 16-28. http://dx.doi.org/10.1111/j.1365-3059.2011.02477.x.

13 Ito S, Maehara T, Tanaka S, Kameya-Iwaki M, Yano S, Kishi F. Cloning of a single-copy DNA sequence unique to Plasmodiophora brassicae. Physiol Molec Plant Pathol. 1997; 50: 289-300. http://dx.doi. org/10.1006/pmpp.1997.0087. 
14 Ito S, Maehara T, Maruno E, Tanaka S, Kameya-Iwaki M, Kishi F. Development of a PCR-based assay for the detection of Plasmodiophora brassicae in soil. J Phytopathol. 1999; 147: 83-88. http://dx.doi.org/ 10.1111/j.1439-0434.1999.tb03812.x.

15 Faggian R, Bulman SR, Lawrie AC, Porter IJ. Specific Polymerase Chain Reaction primers for the detection of Plasmodiophora brassicae in soil and water. Phytopathol. 1999; 89: 392-397. http://dx.doi.org /10.1094/ PHYTO.1999.89.5.392.

16 Staniaszek M, Robak J, Marczewski W. Detection of Plasmodiophora brassicae Wor. by bioassay and nested PCR methods. Vegetable Crops Research Bulletin. 2001; 54: 131-136.

17 Cao T, Tewari J, Strelkov SE. 2007. Molecular detection of Plasmodiophora brassicae, causal agent of clubroot of crucifers, in plant and soil. Plant Dis. 2007; 91: 80-87. http://dx.doi.org/10.1094/PD-91-0080.

18 Li JP, Li Y, Shi YX, Xie XW, A-li C, Li BJ. Development of a Real-Time PCR assay for Plasmodiophora brassicae and its detection in soil samples. J Integr Agric. 2013; 12(10): 1799-1806. http://dx.doi.org/10.1016/ S2095-3119(13)60491-8.

19 Somé A, Manzanares MJ, Laurens F, Baron F, Thomas G, Rouxel F. Variation for virulence on Brassica napus L. amongst Plasmodiophora brassicae collections from France and derived single-spore isolates. Plant Pathol. 1996; 45(3): 432-439. http://dx.doi.org/10. 1046/j.1365-3059.1996.d01-155.x.

20 Notomi T, Okayama H, Masubuchi H, Yonekawa $\mathrm{T}$, Watanabe $\mathrm{K}$, Amino $\mathrm{N}$, Hase $\mathrm{T}$. Loop-mediated isothermal amplification of DNA. Nucleic Acids Res. 2000; 28: E63. http://dx.doi.org/10.1093/ nar/28.12.e63.

21 Mori Y, Notomi T. Loop-mediated isothermal amplification (LAMP): a rapid, accurate, and cost-effective diagnostic method for infectious diseases. J Infect Chemother. 2009; 15: 60-69 http://dx.doi.org/10.1007/s1015 6-009-0669-9.

22 Nagamine K., Hase T., Notomi T. Accelerated reaction by loop-mediated isothermal amplification using loop primers. Mol Cell Probes 2002; 16: 223-229. http://dx.doi.org/10.1006/mcpr.2002.0415.

$23 \mathrm{Kaczmarek} \mathrm{J}$, Jędryczka M. Characterization of two coexisting pathogen populations of Leptosphaeria spp., the cause of stem canker of brassicas. Acta Agrobot. 2011; 64 (2): 3-14.

24 Eckert M, Gout L, Rouxel T, Blaise F, Jędryczka M, Fitt B, Balesdent MH. Identification and characterization of polymorphic minisatellites in the phytopathogenic ascomycete Leptosphaeria maculans. Current Genet. 2005; 47: 37-48. http://dx.doi.org/10.1007/ s00294-004-0539-z.

25 Sun JM, Irzykowski W, Jedryczka M, Han FX. Analysis of the genetic structure of Sclerotinia sclerotiorum (Lib.) de Bary populations from different regions and host plants by Random Amplified Polymorphic DNA markers. J Integr Plant Biol. 2005; 47(4): 385-395. http://dx.doi.org/10.1111/j.1744-7909.2005.00077.x.

26 Buczacki ST, Toxopeus H, Mattusch P, Johnston TD, Dixon DR. Study of physiologic specialization in Plasmodiophora brassicae: Proposals for attempted rationalization through an international approach. Trans Br Mycol Soc. 1975; 65(2): 295-303. http://dx.doi. org/10.1016/S0007-1536(75)80013-1.

27 Manzanares-Dauleux MJ, Divaret I, Baron F, Thomas G. Assessment of biological and molecular variability between and within field isolates of Plasmodiophora brassicae. Plant Pathol. 2001, 50: 165-173. http://dx.doi. org/10.1046/j.1365-3059.2001.00557.x.

28 Strelkov SE, Tewari JP, Smith-Degenhardt E. Characterization of Plasmodiophora brassicae populations from Alberta, Canada. Can J Plant Pathol. 2006; 28: 467-474. http://dx.doi.org/10.1080/07060660609507321.

29 Manzanares-Dauleux MJ, Barret P, Thomas G. Development of a pathotype specific SCAR marker in Plasmodiophora brassicae. Eur J Plant Pathol. 2000; 106: 781-787. http://dx.doi.org/10.1023/A:1026586803761.

30 Jędryczka M, Burzyński A, Brachaczek A, Langwiński W, Song P, K a c z marek J.Loop-mediated isothermal amplification as a good tool to study changing Leptosphaeria populations in oilseed rape plants and air samples. Acta Agrobot. 2013; 66(4): 93-100. http://dx. doi.org/10.5586/aa.2013.055.

31 Ptaszyńska A A, Borsuk G, Woźniakowski G, Gnat S, Małek W. Loop-mediated isothermal amplification (LAMP) assays for rapid detection and differentiation of Nosema apis and N. ceranae in honeybees.; FEMS Microbiol Lett. 2014: 357(1): 40-48. http://dx.doi.org/ 10.1111/1574-6968.12521.

32 Misawa Y, Yoshida A, Saito R, Yoshida H, Okuzumi K, It o N. et al. Application of loop-mediated isothermal amplification technique to rapid and direct detection of methicillin-resistant Staphylococcus aureus (MRSA) in blood cultures. J Infect Chemother. 2007; 13: 134-140. http://dx.doi.org/10.1007/s10156-007-0508-9.

33 Dinh DT, Le MTQ, Vuong CD, Hasebe F, Morita K. An updated Loop-mediated isothermal amplification method for rapid diagnosis of H5N1 avian influenza viruses. Trop Med Health 2011; 39(1): 3-7. http://dx. doi.org/10.2149\%2Ftmh.2010-21

34 Kaneko H, Kawana T, Fukushima E, Suzut a $\mathrm{i}$ T. Tolerance of loop-mediated isothermal amplification to a culture medium and biological substances. J Biochem Biophys Methods 2007; 70: 499-501. http://dx.doi. org/10.1016/j.jbbm.2006.08.008.

35 Tomlinson J, B o on ham N. Potential of LAMP for detection of plant pathogens. CAB Reviews: Perspectives in Agriculture, Veterinary Science, Nutrition and Natural Resources 2008; 3: 1-7. http://dx.doi.org/10.1079/PAV SNNR20083066. 

Wykrywanie Plasmodiophora brassicae
przy zastosowaniu amplifikacji DNA w warunkach izotermicznych $\mathrm{z}$ wykorzystaniem starterów zapętlających (LAMP)

\section{Streszczenie}

Plasmodiophora brassicae powoduje kiłę kapusty, chorobę obniżającą plonowanie i redukującą rentowność uprawy rzepaku. Patogen występuje we wszystkich głównych regionach jego uprawy, a także stanowi poważny problem dla producentów warzyw kapustowatych. Celem badań było opracowanie szybkiego, taniego i niezawodnego sposobu wykrywania $P$. brassicae. W tym celu opracowano metodę amplifikacji DNA w warunkach izotermicznych z wykorzystaniem starterów zapętlających (LAMP). Do detekcji wykorzystano polimerazę GspSSD, wyodrębnioną z bakterii Geobacillus sp., umożliwiającą zastępowanie nici DNA bez potrzeby zmiany profilu temperatury. Ekstrakcję DNA z wyrośli na korzeniach wykonano z zastosowaniem zmodyfikowanej metody CTAB. Reakcję prowadzono przez 60 minut $\mathrm{w}$ temperaturze $62^{\circ} \mathrm{C}$. Wyniki zbierano przy zastosowaniu systemu CFX96 Real Time PCR Detection System (BioRad) lub Gerie II Amplificator (Optigene). Opracowana metoda była łatwa do wykonania, szybka, dokładna i niezależna od wieku badanej rośliny. LAMP był testem mniej czułym aniżeli opisane w literaturze metody ilościowego PCR; umożliwił wykrywanie 5000 zarodników w $1 \mathrm{~mL}$ zawiesiny. Jest to jednak metoda znacznie łatwiejsza do wykonania i zdecydowanie tańsza, co czyni ją przydatną do detekcji $P$. brassicae w przypadku konieczności oceny jego obecności w licznych próbach polowych.

Handling Editor: Elżbieta Weryszko-Chmielewska

This is an Open Access digital version of the article distributed under the terms of the Creative Commons Attribution 3.0 License (creativecommons.org/licenses/by/3.0/), which permits redistribution, commercial and non-commercial, provided that the article is properly cited. 
